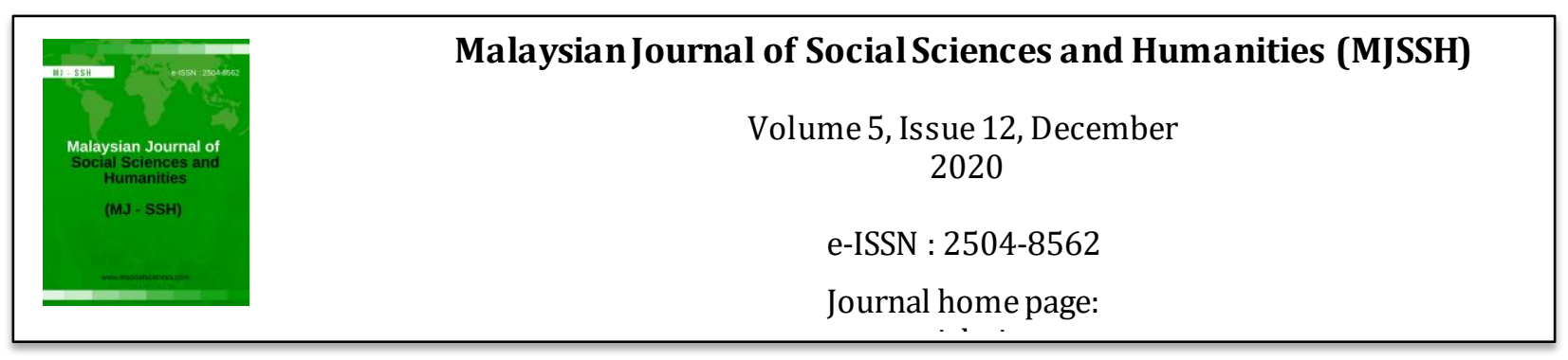

\title{
Faktor dan Implikasi Daya Tahan dalam Pembelajaran Matematik: Sorotan Literatur Bersistematik
}

\author{
Norfadilah Binti Mat'1, Siti Mistima Maat1 \\ ${ }^{1}$ Fakulti Pendidikan, Universiti Kebangsaan Malaysia (UKM) \\ Correspondence: Norfadilah Binti Mat (norfadilahmat@yahoo.com)
}

\begin{abstract}
Abstrak
Kekuatan untuk mengatasi dan melalui suatu keadaan yang sukar dalam melaksanakan tugas memerlukan seseorang individu mempunyai daya tahan yang tinggi. Faktor penyebab ketahanan seorang perlu diketahui bagi menangani masalah yang dihadapi dalam pembelajaran matematik. Kajian sistematik ini adalah meninjau elemen-elemen penyelidikan empirikal terhadap daya tahan, faktor-faktor yang mempengaruhi daya tahan dan implikasi kajian daya tahan terhadap pembelajaran matematik. Pencarian artikel melalui dua pangkalan utama data Scopus dan Science Direct dan beberapa pangkalan data tambahan dalam lingkungan tahun 2015 sehingga 2020. Penetapan kriteria merangkumi seperti kajian melibatkan bidang pendidikan, kajian yang menguji dan menentukan daya tahan dalam pembelajaran matematik dan jenis responden yang terdiri daripada guru dan pelajar. Data pencarian dianalisis melalui kaedah Preferred Reporting Items for Systematic reviews and Meta-Analyses (PRISMA) dan mendapati sebanyak 31 kajian yang terpilih dalam kajian sistematik ini. Dapatan kajian mendapati elemen penyelidikan melalui reka bentuk kuantitatif dan instrumen soal selidik sebagai trend kajian utama dalam menentukan daya tahan pelajar dalam pembelajaran matematik. Hasil kajian juga mendapati terdapat tiga faktor utama mempengaruhi daya tahan seperti faktor afektif yang melibatkan tingkah laku dan personaliti, penyelesaian masalah dan pendekatan pengajaran serta implikasi daya tahan yang dapat memberi kesan kepada guru, pelajar, sekolah dan ibu bapa. Dapatan kajian boleh dimanfaatkan kepada semua golongan bagi memastikan pembelajaran matematik bukan hanya berpunca daripada kesukaran pelajar menyelesaikan masalah. Namun faktor lain juga dipertimbangkan serta kesan kajian daya tahan dapat memberi pendedahan kepada semua pihak untuk membantu dan berkerjasama bagi mengekalkan daya tahan pelajar dan guru terhadap matematik.
\end{abstract}

Kata kunci: daya tahan, matematik, ketahanan matematik

\section{Factors And Implication Of Resilience In Mathematics Learning : Systematic Literature Review}

\begin{abstract}
The strength to overcome and go through a difficult situation in performing a task requires an individual to possess high resilience. Factors that cause one's endurance need to be recognised to deal with problems encountered in learning mathematics. This systematic study examines the elements of empirical research on resilience, factors that influence resilience and the implications of resilience research on mathematical learning. Article search may include two main databases of Scopus and Science Direct also, some additional databases in the period from 2015 to 2020. Criteria setting includes such studies involving
\end{abstract}


education, studies that test and determine resilience in mathematics learning and the type of respondents consisting of teachers and students. Search data were analysed through the method of Preferred Reporting Items for Systematic reviews and Meta-Analyzes (PRISMA) and a total of 31 selected studies was found in this systematic study. The findings of the study found that research elements through quantitative design and questionnaire instruments are the main research trend in determining students' resilience in mathematics learning. The results also found that there are three main factors influencing resilience which are affective factors involving behaviour and personality, problem solving and teaching approaches as well as resilience implications that can affect teachers, students, schools, and parents. The findings of the study can be utilized by all parties to ensure that mathematics learning is not only caused by the difficulty of students solving problems. However, other factors and effects of resilience research can also be taken into consideration in order to give exposure to everyone involved in helping and working together to maintain students' and teachers' resilience towards mathematics.

Keywords: resilience, mathematics, review

\section{Pengenalan}

Seorang yang berdaya tahan mampu memberikan reaksi dan tingkah laku yang positif terhadap sebarang bentuk kesukaran, cabaran mahupun halangan. Ketahanan mengambarkan kemampuan individu untuk bangkit semula bagi menyesuaikan diri dengan keadaan yang menekan secara positif (Joyce et al., 2018). Kesukaran dalam mempelajari atau menyampaikan suatu ilmu pengetahuan merupakan satu perkara yang harus dihadapi oleh seoran guru ataupun pelajar. Bagi seorang tenaga pengajar samada ada guru, pensyarah atau pakar dalam bidang matematik, pasti menghadapi kesukaran dalam proses menyampaikan ilmu pengetahuan. Memahami kandungan, tingkah laku pelajar menjadi satu cabaran dan menguji tahap ketahanan mereka.

Daya tahan boleh memberi pelbagai tafsiran kepada diri seorang individu samada berdaya tahan dalam mengatasi kesukaran melaksanakan suatu tugasan. Mahupun kesukaran menghadapi tekanan luar menganggu kekuatan dalam sehingga menyebabkan kegelisahan. Definisi daya tahan bagi seorang pelajar adalah berkemampuan menangani masalah dan rintangan yang mustahil namun dapat dilalui dalam keadaan yang baik (A. J. B. Hutauruk et al., 2019). Selain itu daya tahan dapat menjadikan seseorang berkebolehan menyerlahkan potensi diri, meningkatkan kemampuan dan domain afektif diri. Memiliki ketahanan diri dalam mempelajari matematik merupakan suatu perkara yang penting dalam proses penyelesaian masalah (Harsela \& Asih, 2020). Bagi seorang pelajar cabaran yang dilalui ketika mempelajari matematik boleh menyebabkan perasaan tertekan, gusar dan berasa ketakutan. Akibatnya pelajar tidak berdaya tahan untuk meneruskan tugasan yang diberi sehingga mereka beranggapan bahawa matematik merupakan mata pelajaran yang sukar dikuasai. Persepsi yang negatif ini akan terus berlanjutan sehingga ke peringkat pengajian yang lebih tinggi

\section{Sorotan Literatur}

Menurut Harsela et al. (2020) seorang pelajar yang berdaya tahan dapat menilai, mengatasi dan memperbaiki diri ke arah yang lebih baik. Mereka berkemampuan serta berkebolehan memupuk keyakinan dalaman diri untuk berdaya tahan dengan tugasan yang mencabar. Pelajar sanggup berusaha memahami dan menguasai konsep matematik bagi membolehkan mereka dapat meneruskan ke aktiviti yang seterusnya. Perkara ini amat dituntut bagi melahirkan generasi modal insan yang berkebolehan untuk berdaya tahan dalam pasaran kerja. Seandainya pelajar berkemampuan menangani kesukaran dalam pelajar mereka juga berkeupayaan untuk mengekalkan ketahanan dalam bidang pekerjaan. Revolusi perindustrian era 4.0 menuntut perubahan paradigma dalam bidang pendidikan. Perubahan perlu dilaksanakan bagi memastikan pelajar terus berdaya tahan supaya melahirkan sikap dan kemahiran kompetensi dalam pembelajaran matematik (Saleh \& Rosli, 2019). 
Ketahanan dalam matematik apabila tidak mengawal perasaan dan emosi ketika menyelesaikan tugasan yang mencabar. Mereka merasakan kesukaran untuk menguasai konsep asas dan sering diberi tugasan yang rutin. Rentetan hal tersebut telah menjadi kebiasaan bagi pelajar menyelesaikan masalah matematik yang rutin bagi mengelakkan ketahanan diri tergugat apabila berhadapan dengan situasi yang baru. Hal ini menyebabkan pelajar tidak dapat meningkatkan kemahiran berfikir aras tinggi, tidak dapat mencari jalan penyelesaian dengan usaha sendiri, penguasaan konsep yang leman serta tidak dapat mengembangkan potensi diri untuk berfikir secara kritis dan kreatif (Salehudin \& Zakaria, 2017)

Selain itu permasalahan yang wujud apabila pelajar yang berkebolehan sahaja yang dapat menyelesaikan tugasan matematik dengan baik. Sedangkan terdapat faktor lain yang menyebabkan pelajar tidak berdaya tahan. Menurut Laelasari et al. (2019a) kajian penyelidikan perlu dilaksanakan bagi mengekalkan ketahanan dalam diri pelajar. Pelajar yang berdaya tahan mampu mengatasi segala halangan dalam menyelesaikan masalah matematik yang sukar.

Justeru itu tinjauan sistematik yang dilaksanakan melalui empirikal data adalah bagi menjawab persoalan kajian yang telah ditentukan seperti berikut : (1) Apakah elemen-elemen penyelidikan empirikal terhadap daya tahan dalam pembelajaran matematik? (2) Apakah faktor yang mempengaruhi daya tahan dalam pembelajaran matematik? dan (3) Apakah implikasi kajian terhadap bidang pendidikan?

\section{Metod Kajian}

Bahagian ini akan menerangkan bagaimana pemilihan kajian dalam tinjauan sistematik berdasarkan kaedah Preferred Reporting Items for Systematic reviews and Meta-Analyses (PRISMA). Bahagian ini akan menerangkan bagaimana prosedur pengumpulan data yang bermula daripada penggunaan kata kunci dalam pencarian data, kriteria kelayakan dan pengecualian bagi setiap kajian sehingga kajian penuh dipilih bagi kajian sistematik ini.

\section{PRISMA}

Kajian sistematik adalah mengumpulkan kajian sorotan lepas dengan kriteria tertentu serta langkah yang sistematik dalam pencarian data. Tujuan kajian adalah memberikan ringkasan daripada tinjauan pengkaji secara kritis berdasarkan persoalan kajian (Kharlamov, 2016). Menggunakan sumber pangkalan data utama daripada Scopus dan Science Direct serta beberapa pangkalan data lain. Menurut Gusenbauer et al. (2020) pemilihan dua sumber pangkalan tersebut antara "search engines" yang membantu mendapat kajian yang bersesuaian dan berkualiti bagi kajian sistematik.

Langkah seterusnya menggunakan kaedah PRISMA yang dapat membantu pengkaji menentukan kajian yang diperlukan berdasarkan persoalan kajian (Jamaludin et al., 2020). Terdapat empat langkah dalam carta alir PRISMA bagi menentukan kajian yang bersesuaian dengan kehendak pengkaji iaitu mengenai daya tahan dalam bidang matematik. Empat garis panduan bermula daripada pengenalpastian (Identification), penapisan (Screening), kelayakan (Eligibility) dan termasuk (Included).

Melalui langkah pengenalpastian pengkaji menjumpai sebanyak 478 kajian dengan menggunakan pencarian kata kunci resilience dan mathematics serta mathematical resilience dengan ciri "Open Access". Bilangan kajian tersebut diperolehi melalui penetapan kriteria kelayakan dan pengecualian berdasarkan jadual 1 iaitu tahun pencarian kajian bermula tahun 2015 sehingga 2020. Pemilihan kajian hanya menggunakan Bahasa Inggeris serta pemilihan kajian adalah empirikal data seperti artikel dan conference paper. Cabaran yang dihadapi pengkaji dalam kajian sistematik adalah mencari bahan atau bukti yang relevan yang mampu menjawab persoalan kajian secara empirikal. Bahan akademik seperti tesis dan disertasi, conference paper boleh digunakan sebagai bukti atau bahan sokongan dalam kajian tinjauan sistematik (Paez, 2017). 
DOI: https://doi.org/10.47405/mjssh.v5i12.576

Jadual 1 : Kriteria yang ditetapkan dalam pencarian kajian

\begin{tabular}{lll}
\hline \multicolumn{1}{c}{ Kriteria } & Kelayakan & Pengecualian \\
\hline Tahun pencarian & 2015 sehingga 2020 & $<2015$ \\
Bahasa & Bahasa Inggeris & Selain Bahasa Inggeris \\
Jenis literatur & Empirikal Data & $\begin{array}{l}\text { Buku, majalah, kajian tinjauan } \\
\text { sistematik, koleksi bahan persidangan }\end{array}$ \\
Responden & Pelajar dan guru & Selain pelajar dan guru \\
\hline
\end{tabular}

Langkah seterusnya adalah penapisan (Screening) berdasarkan jenis literatur dalam bidang pendidikan. Tumpuan kajian adalah mengenai daya tahan dalam pembelajaran matematik dan melibatkan responden pelajar dan guru sahaja. Hasil penapisan sebanyak 538 kajian dikeluarkan kerana tidak memenuhi syarat yang ditetapkan pengkaji. Kajian yang dikeluarkan adalah seperti kajian sistematik, proceeding paper, kajian alam sekitar, pengangkutan, bidang kejuruteraan dan bidang perubatan. Hasil kelayakan (Eligibility) pengkaji memperolehi sebanyak 98 kajian yang layak untuk diakses sepenuhnya. Kajian tersebut merupakan pencarian daripada enam sumber pangkalan data iaitu Scopus, Science Direct, Google Scholar, Oxford Academic, SAGE Journals dan ERIC. Melalui langkah kelayakan pengkaji akan menganalisis secara kritis bagi memperolehi kajian yang dikehendaki. Langkah termasuk (Included) mendapati terdapat 31 kajian yang dipilih bagi kajian sistematik ini. Setelah 67 kajian dikecualikan kerana jenis responden tidak memenuhi syarat yang ditetapkan pengkaji. Terdapat kajian yang mengabungkan pelajar dengan penjaga dan pelajar dengan orang awam. Berdasarkan rajah 1 menunjukkan carta alir yang telah diadaptasi daripada Moher et al. (2009) yang menunjukkan keempat-empat langkah yang telah dilaksanakan bagi memperolehi data bagi kajian sistematik ini. Aplikasi PRISMA memberi pelbagai kelebihan antaranya adalah dapat menentukan dengan jelas persoalan kajian dalam penyelidikan sistematik, mengenal pasti kriteria dalam satu artikel yang perlu dimasukkan atau dikeluarkan dan membantu mendapatkan pangkalan data bagi kajian saintifik literatur pada masa yang ditetapkan (Ramli et al., 2019).

Rajah 1: Carta alir bagi pencarian data menggunakan aplikasi PRISMA

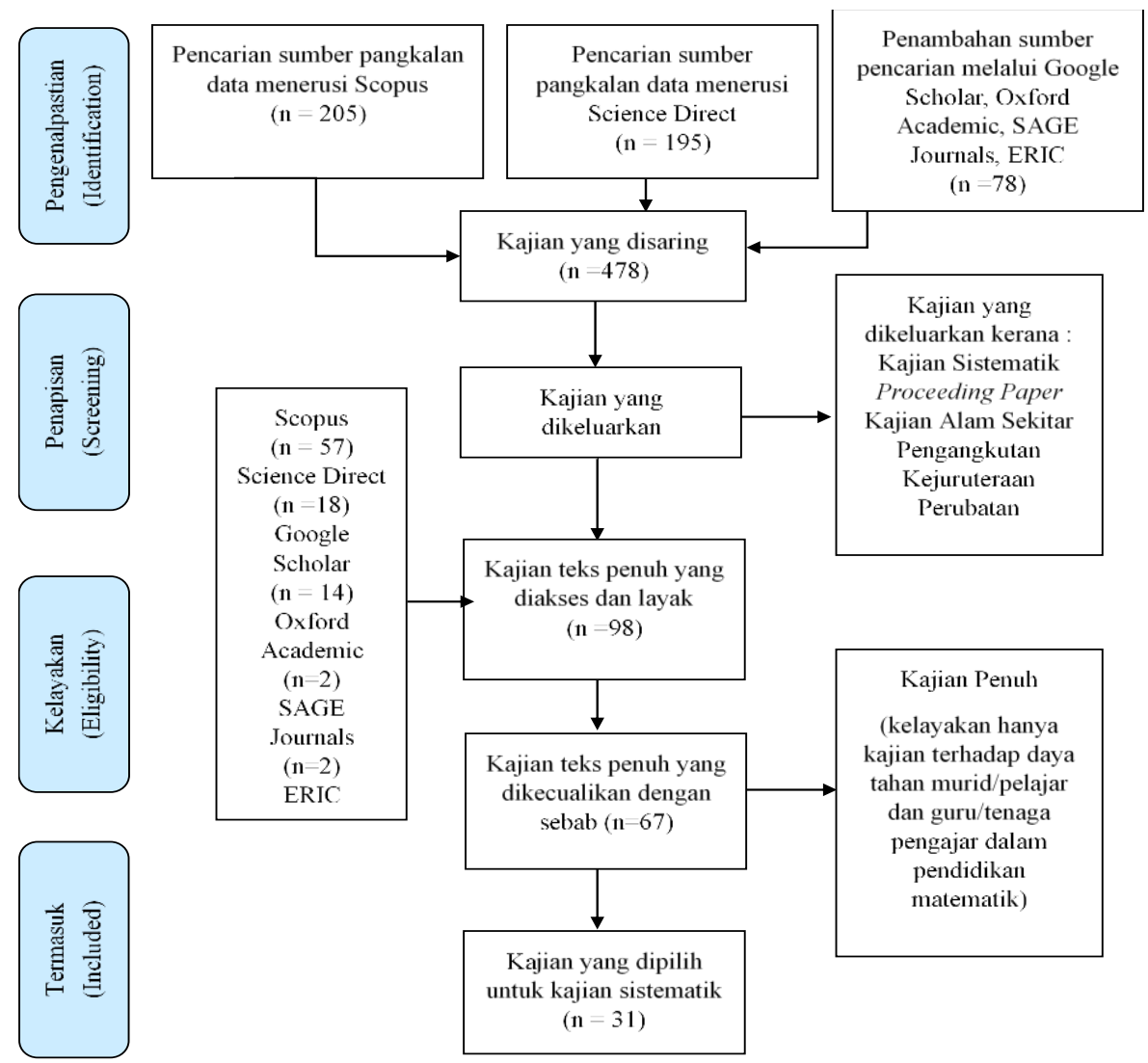




\section{Hasil Kajian}

Bahagian ini akan menjelaskan tiga persoalan yang dikemukan pengkaji dalam kajian sistematik berkaitan dengan daya tahan dalam pembelajaran matematik. Penjelasan merangkumi elemen penyelidikan seperti trend reka bentuk dan jenis instrumen bagi menentukan daya tahan dalam penyelidikan, faktor yang mempengaruhi kajian daya tahan dalam pembelajaran matematik dan implikasi kajian dalam bidang pendidikan.

\section{Reka Bentuk Kajian}

Berdasarkan jadual 2 mendapati terdapat tiga jenis penyelidikan iaitu secara kuantitatif, kualitatif dan gabungan bagi kuantitatif dan kualitatif. Berdasarkan analisis mendapati penyelidikan secara kuantitatif merupakan pemilihan penyelidik dalam menjalankan kajian terhadap daya tahan dalam pembelajaran matematik. Sebanyak 12 kajian terdiri daripada kajian tinjauan, 9 kajian merupakan reka bentuk kajian secara eskperimen dan kuasi eksperimen. Manakala terdapat 2 kajian menggunakan reka bentuk secara korelasi. Analisis ini mendapati kajian kuantitatif merupakan jenis kajian paling tinggi sebanyak $71 \%$ berbanding kajian kualitatif dan gabungan kajian.

Jadual 2 : Analisis jenis penyelidikan dan reka bentuk kajian

\begin{tabular}{lll}
\hline Penyelidikan & Reka Bentuk Kajian & Kajian \\
\hline \multirow{3}{*}{ Kuantitatif } & Eksperimental \& Kuasi- & (Ariyanto et al., 2017, 2019; Fitri et \\
& Eksperimental & al., 2019; Hafiz et al., 2017; \\
& & Hendriana et al., 2019; A. J. B. \\
& & Hutauruk et al., 2019; Kahveci \& \\
& Bulut Serin, 2017; Laelasari et al., \\
& 2019a, 2019b) \\
\cline { 2 - 3 } & Korelasi & (A. J. Hutauruk \& Priatna, 2017; \\
& Rokhmah et al., 2019) \\
\cline { 2 - 3 } & Kajian Tinjauan & (Attami et al., 2020; Findik, 2016; \\
& & Gü, 2018; Harsela \& Asih, 2020; Id et \\
& al., 2019; Jajuri et al., 2019; Joy, \\
& 2019; Kooken et al., 2016; Mota et \\
& & al., 2016; Nelwan et al., 2018; \\
& Santiago Carrillo et al., 2019; Zanty \\
& et al., 2019) \\
\hline Kualitatif & Kajian Kes & (Bailey, 2017; Caceres Carvajal et al., \\
& & 2019; Mullet et al., 2018; Srikantaiah \\
& \& Eichhorn, 2018) \\
\cline { 2 - 3 } & Naratif & (Lutovac, 2019) \\
\hline Kuantitatif \& & & (Afriyanti et al. 2018; Asih 2021; \\
Kualitatif & & Lyakhova et al. 2019) \\
\hline
\end{tabular}

Kajian secara ekperimental dan kuasi eskperimental adalah pilihan kedua penyelidik kerana ingin membandingkan dua kumpulan terhadap pendekatan atau kaedah bagi menentukan jenis daya tahan dalam pembelajaran matematik. Kajian secara kualitatif merupakan kedua jenis kajian dalam daya tahan yang melibatkan kajian kes dan naratif. Kajian kualitatif dapat mengkaji secara semulajadi dengan lebih mandalam. Penafsiran yang dilaksanakan mengikut fenomena dan persekitaran responden. Kajian secara naratif digunakan dalam mengenal pasti maklumat yang dikehendaki melalui penceritaan (Caceres Carvajal et al., 2019; Lutovac, 2019). Seterusnya kajian gabungan bagi kuantitatif dan kualitatif sebanyak 3 kajian sahaja kerana tempoh pelaksanaan yang panjang dalam mengendalikan kajian tersebut. Secara keseluruhan kajian kuantitatif merupakan jenis kajian yang banyak dilaksanakan sepanjang lima tahun ini. Kajian ini mudah dijalankan kerana tempoh pelaksanaan yang tidak terlalu lama. Manakala kajian secara eskperimen merupakan kaedah yang turut sesuai bagi mengetahui tahap 
keberkesanan suatu pemboleh ubah dengan membuat perbandingan antara kumpulan yang paling baik iaitu kumpulan rawatan dan kumpulan kawalan (Cheong et al., 2018).

\section{Instrumen Kajian}

Bahagian ini akan menerangkan jenis instrumen berkaitan menentukan daya tahan dalam pembelajaran matematik. Instrumen kajian merupakan peralatan, perisian atau perkakasan yang digunakan untuk memungut dan mengumpul maklumat. Data diperolehi melalui sasaran kajian seperti soal selidik, buku catatan, video, kamera, perakam suara atau komputer dan penggunaan perisian (Mohamed Berawi, 2017). Jenis instrumen adalah soal selidik, ujian, protokol temu bual, borang pemerhatian dan dokumen analisis.

Merujuk jadual 3 mendapati instrumen jenis soal selidik yang paling tinggi digunakan sebanyak 25 kajian. Hanya beberapa kajian sahaja yang menyatakan jenis skala yang digunakan dalam soal selidik tersebut. Soal selidik yang digunakan menggunakan skala likert dengan lima mata (Attami et al., 2020; Harsela \& Asih, 2020) dan skala likert empat mata (Findik, 2016; Id et al., 2019). Kajian mendapati penyelidik merujuk dan mengubah suai jenis skala bagi daya tahan seperti Mathematical Resilience Scale (MRS) (Gü 2018 ; Joy 2019). Penggunaan instrumen yang telah kukuh dapat memberi panduan kepada penyelidik bagi mengubah suai item mengikut kesesuaian populasi kaji supaya alat tersebut dapat mengukur apa yang sepatutnya diukur.

Jadual 3 : Jenis instrumen kajian

\begin{tabular}{|c|c|c|c|c|c|}
\hline Kajian & $\begin{array}{l}\text { Soal } \\
\text { Selidik }\end{array}$ & Ujian & $\begin{array}{c}\text { Protokol } \\
\text { Temu } \\
\text { Bual }\end{array}$ & $\begin{array}{c}\text { Borang } \\
\text { Pemerhatian }\end{array}$ & $\begin{array}{l}\text { Dokumen } \\
\text { Analisis }\end{array}$ \\
\hline (Asih, 2021) & l & & I & l & l \\
\hline (Harsela \& Asih, 2020) & l & & & & \\
\hline (Attami et al., 2020) & I & & & & \\
\hline $\begin{array}{l}\text { (A. J. B. Hutauruk et al., } \\
\text { 2019) }\end{array}$ & I & l & & & \\
\hline (Joy, 2019) & I & & & & \\
\hline (Laelasari et al., 2019a) & I & I & & & \\
\hline (Fitri et al., 2019) & I & I & & & \\
\hline $\begin{array}{l}\text { (Caceres Carvajal et al., } \\
\text { 2019) }\end{array}$ & & & l & l & / \\
\hline (Hendriana et al., 2019) & I & I & & & \\
\hline (Lyakhova \& Neate, 2019) & I & & l & l & l \\
\hline (Lutovac, 2019) & & & I & I & I \\
\hline (Rokhmah et al., 2019) & l & & & & \\
\hline $\begin{array}{l}\text { (Santiago Carrillo et al., } \\
\text { 2019) }\end{array}$ & l & & l & l & / \\
\hline (Zanty et al., 2019) & I & & & & \\
\hline (Id et al., 2019) & I & & & & \\
\hline (Jajuri et al., 2019) & I & & & & \\
\hline (Laelasari et al., 2019b) & I & I & & & \\
\hline (Ariyanto et al., 2019) & I & I & & & \\
\hline (Mullet et al., 2018) & & & I & I & I \\
\hline (Nelwan et al., 2018) & I & & & & \\
\hline (Gü, 2018) & I & & & & \\
\hline $\begin{array}{l}\text { (Srikantaiah \& Eichhorn, } \\
\text { 2018) }\end{array}$ & & & l & l & l \\
\hline (Afriyanti et al., 2018) & l & l & l & l & l \\
\hline $\begin{array}{l}\text { (Kahveci \& Bulut Serin, } \\
\text { 2017) }\end{array}$ & I & I & & & \\
\hline
\end{tabular}


DOI: https://doi.org/10.47405/mjssh.v5i12.576

\begin{tabular}{lllll}
\hline (Hafiz et al., 2017) & $/$ & & & \\
\hline (Ariyanto et al., 2017) & $/$ & $/$ & & \\
\hline (A. J. Hutauruk \& Priatna, & $/$ & & & \\
2017) & & & & \\
\hline (Bailey, 2017) & & $/$ & \\
\hline (Kooken et al., 2016) & $/$ & & & \\
\hline (Mota et al., 2016) & $/$ & & & \\
\hline (Findik, 2016) & $/$ & & & \\
\hline
\end{tabular}

Bagi kajian secara eksperimen alat pengukuran seperti ujian sebanyak 9 kajian telah diberikan kepada sampel kajian. Ujian ini diberikan semasa menjalankan pendekatan atau kaedah yang diuji seperti ujian mathematical prior knowledge (MPK) dan ujian bagi topik Polyhedron (Hafiz et al., 2017; A. J. B. Hutauruk et al., 2019). Keberhasilan suatu kajian boleh dilihat melalui ujian yang diberi kepada kumpulan sasaran. Alat pengukur menerusi kajian kualitatif seperti protokol temu bual, borang pemerhatian dan dokumen analisis sebanyak 9 kajian. Protokol temu bual dalam kajian tersebut menggunakan jenis temu bual separuh berstruktur (Bailey, 2017; Caceres Carvajal et al., 2019). Alat kajian tersebut memerlukan tempoh masa persediaan yang lebih lama kerana setiap temu bual harus realistik dengan latar belakang responden (Lichtman, 2014; Liskin, 2011). Penyelidik harus mahir dengan teknik temu bual supaya isu-isu seperti emosi harus ditangani sebelum memulakan prosedur temu bual. Sumber temu bual merupakan asas andaian bagi penyelidik bagi menjawab persoalan kajian serta maklumat yang diperlukan dalam kajian. Secara keseluruhan soal selidik merupakan trend pilihan penyelidik sebagai instrumen yang dapat menentukan tahap daya tahan seseorang individu. Pemilihan item soalan yang kukuh mampu memberikan maklumat kepada penyelidik. Bagi menjadikan penyelidikan tersebut lebih produktif kajian secara eskperimen juga dipilih bagi mengetahui lebih lanjut mengenai kumpulan kajian. Selain itu maklumat yang mendalam boleh diperolehi melalui protokol temu bual. Borang pemerhatian juga merupakan sumber maklumat yang digunakan penyelidikan kualitatif. Bagi mendapat hasil pemerhatian yang berkualiti, penyelidik perlu menjalankan pemerhatian secara sistematik. Mencatat setiap perkara yang berlaku dengan menggunakan bantuan alat pemerhatian seperti senarai semak, rakaman audio dan rakaman video (Cheong et al., 2018).

\section{Faktor yang Mempengaruhi Daya Tahan dalam Matematik}

Setiap individu pasti mengalami kesukaran dalam menyelesaikan suatu tugasan kerja atau urusan seharian. Secara amnya, setiap pelajar mahupun pendidik pasti menghadapi kesukaran untuk menguruskan pembelajaran atau pengajaran. Pelbagai faktor penyumbang yang menyebabkan kesukaran itu wujud sehingga mempengaruhi daya tahan seseorang. Hasil dapatan mendapati tiga faktor penyumbang iaitu personaliti dan tingkah laku, penyelesaian masalah, pendekatan pengajaran dan lain-lain.

Jadual 4 : Jenis faktor yang mempengaruhi daya tahan dalam matematik

\begin{tabular}{|c|c|c|}
\hline Faktor & Bilangan & Kajian \\
\hline $\begin{array}{l}\text { Afektif (Personaliti \& } \\
\text { Tingkah Laku) }\end{array}$ & 8 & $\begin{array}{l}\text { (Asih, 2021; Caceres Carvajal et al., 2019; } \\
\text { Findik, 2016; Id et al., 2019; Joy, 2019; } \\
\text { Lyakhova \& Neate, 2019; Mullet et al., 2018; } \\
\text { Santiago Carrillo et al., 2019) }\end{array}$ \\
\hline Penyelesaian Masalah & 11 & $\begin{array}{l}\text { (Ariyanto et al. 2017; Attami et al. 2020; Bailey } \\
\text { 2017; Harsela et al. 2020; A. J. Hutauruk et al. } \\
\text { 2017; Kahveci et al. 2017; Laelasari et al. 2019b; } \\
\text { Lutovac 2019; Rokhmah et al. 2019; Srikantaiah } \\
\text { et al. 2018; Zanty et al. 2019) }\end{array}$ \\
\hline Pendekatan Pengajaran & 9 & $\begin{array}{l}\text { (Afriyanti et al. 2018; Ariyanto et al. 2019; Fitri } \\
\text { et al. 2019; Hafiz et al. 2017; Hendriana et al. }\end{array}$ \\
\hline
\end{tabular}




\begin{tabular}{ll}
\hline & $\begin{array}{l}\text { 2019; A. J. B. Hutauruk et al. 2019; Laelasari et } \\
\text { al. 2019a; Mota et al. 2016; Nelwan et al. 2018) }\end{array}$ \\
\hline Lain-lain & $\begin{array}{l}\text { (Gü, 2018; Jajuri et al., 2019; Kooken et al., } \\
\text { 2016) }\end{array}$ \\
\hline
\end{tabular}

Berdasarkan jadual 4 mendapati faktor penyelesaian masalah dengan 11 kajian merupakan faktor tertinggi yang menyumbang kepada daya tahan seseorang individu. Manakala faktor kedua yang mempengaruhi daya tahan pelajar adalah disebabkan pendekatan pengajaran sebanyak 9 kajian. Faktor yang ketiga adalah berkaitan afektif yang merujuk kepada personaliti dan tingkah laku pelajar dan guru sebanyak 8 kajian. Personaliti ini merangkumi seperti emosi, motivasi, sikap, memori dan ingatan serta melibatkan perasaan dengan pengaruh persekitaran. Manakala faktor yang terakhir sebanyak 3 kajian adalah berkaitan pembinaan instrumen yang meliputi tiga aspek iaitu Value, Struggle dan Growth.

\section{Implikasi daya tahan terhadap pembelajaran dan pengajaran matematik}

Kesan daya tahan dapat mengubah seseorang individu melakukan perubahan ke arah lebih baik. Perubahan yang dialami boleh merangkumi kepada intelek, emosi atau persekitaran sekeliling. Ketahanan tersebut membuat individu mempunyai ketekatan yang baik untuk mencapai hasrat yang diinginkan. Walaupun apa sekalipun cabaran yang mendatang individu tersebut dapat mengatasi kesukaran tersebut dengan nekad diri yang berdaya tahan (Irmohizam Ibrahim \& Muhammad Hussin, 2016). Bahagian ini akan menyatakan implikasi kajian daya tahan kepada tujuh elemen iaitu kesan kepada guru dan pelajar, pelajar, pelajar dan sekolah, pelajar dan ibu bapa, guru, pelajar dan ibu bapa, pelajar, sekolah dan ibu bapa dan guru pelajar dan sekolah. Hasil dapatan ini berdasarkan implikasi yang dinyatakan oleh penyelidik berdasarkan kajian yang telah dilaksanakan.

Berdasarkan jadual 5 mendapati implikasi kesan kepada guru dan pelajar merupakan elemen yang paling tinggi dengan 13 kajian. Elemen kedua adalah kesan kepada pelajar dengan 6 kajian yang meliputi perubahan kepada pencapaian, keyakinan, motivasi dan kemahiran insaniah. Seterusnya elemen kepada pelajar dan sekolah dengan adalah sebanyak 5 kajian yang merangkumi kepada persekitaran sekolah dan peranan kaunselor. Manakala terdapat 2 kajian bagi elemen ini menyatakan pelajar yang mendapat sokongan daripada keluarga mempunyai minat yang tinggi terhadap matematik. Terdapat 3 kajian yang menyatakan seperti peranan guru dalam menyediakan kemudahan pengajaran berasaskan teknologi dapat mengekalkan ketahanan pelajar semasa dalam kelas (Mota et al., 2016). Kajian seterusnya adalah elemen yang memberi kesan kepada pelajar, sekolah dan ibu bapa serta guru, pelajar dan sekolah dengan 1 kajian. Kajian ini menerangkan terapi tingkah laku berdasarkan skema kognitif dapat meningkatkan daya tahan dalam matematik (Kahveci \& Bulut Serin, 2017).

Jadual 5 : Implikasi daya tahan terhadap pembelajaran matematik

\begin{tabular}{|c|c|c|c|c|c|c|c|c|c|c|}
\hline \multirow[t]{2}{*}{ Kajian } & \multicolumn{2}{|c|}{ Guru } & \multicolumn{4}{|c|}{ Pelajar } & \multicolumn{2}{|c|}{ Sekolah } & \multicolumn{2}{|c|}{ Ibu Bapa } \\
\hline & PP & PG & $\mathbf{P}$ & $\mathbf{K}$ & $\mathbf{M}$ & KI & $\mathbf{K}$ & PS & $\mathbf{S}$ & TH \\
\hline (Asih, 2021) & 1 & & & & & I & & & & \\
\hline (Harsela \& Asih, 2020) & & & I & & l & & & & & \\
\hline (Attami et al., 2020) & & & & & I & I & & & & \\
\hline $\begin{array}{l}\text { (A. J. B. Hutauruk et al., } \\
\text { 2019) }\end{array}$ & I & & I & & & & & & & \\
\hline (Joy, 2019) & & & & & I & & I & & & \\
\hline (Laelasari et al., 2019a) & l & & l & & & & & & & \\
\hline (Fitri et al., 2019) & l & & I & & & & & & & \\
\hline $\begin{array}{l}\text { (Caceres Carvajal et al., } \\
\text { 2019) }\end{array}$ & I & & & l & & & & & & \\
\hline (Hendriana et al., 2019) & I & & & & I & & & & & \\
\hline (Lyakhova \& Neate, 2019) & & & & l & & & & & I & \\
\hline (Lutovac, 2019) & & 1 & & 1 & & & & & & \\
\hline
\end{tabular}




\begin{tabular}{|c|c|c|c|c|c|c|c|c|c|c|}
\hline (Rokhmah et al., 2019) & I & & I & & & & & & I & \\
\hline $\begin{array}{l}\text { (Santiago Carrillo et al., } \\
\text { 2019) }\end{array}$ & & & & & I & & & I & & \\
\hline (Zanty et al., 2019) & l & & l & & & & & & & \\
\hline (Id et al., 2019) & & & l & I & & & & & & \\
\hline (Jajuri et al., 2019) & I & & & & & I & & & & \\
\hline (Laelasari et al., 2019b) & & & & l & & & & I & & \\
\hline (Ariyanto et al., 2019) & I & & I & & & & & & & \\
\hline (Mullet et al., 2018) & & & & I & & I & & & & \\
\hline (Nelwan et al., 2018) & I & & I & & & & & I & & \\
\hline (Gü, 2018) & & & l & l & & & & & & \\
\hline $\begin{array}{l}\text { (Srikantaiah \& Eichhorn, } \\
\text { 2018) }\end{array}$ & & & I & I & I & & & & I & \\
\hline (Afriyanti et al., 2018) & I & & I & l & & & & & & \\
\hline $\begin{array}{l}\text { (Kahveci \& Bulut Serin, } \\
\text { 2017) }\end{array}$ & & & & l & & & & I & & I \\
\hline (Hafiz et al., 2017) & I & & I & l & & & & & & \\
\hline (Ariyanto et al., 2017) & & I & l & I & & & & & & \\
\hline $\begin{array}{l}\text { (A. J. Hutauruk \& Priatna, } \\
\text { 2017) }\end{array}$ & & & l & l & I & & & & & \\
\hline (Bailey, 2017) & l & & & l & & & & & I & \\
\hline (Kooken et al., 2016) & & & I & l & & & I & & & \\
\hline (Mota et al., 2016) & l & & / & & & & & & & I \\
\hline (Findik, 2016) & & & 1 & 1 & & & & 1 & & \\
\hline
\end{tabular}

\section{Petunjuk :}

Guru : PP : Pendekatan Pengajaran

PG : Pengetahuan Guru

Pelajar : P : Pencapaian K : Keyakinan

M: Motivasi KG : Kemahiran Insaniah

Sekolah : K : Kaunselor PS : Persekitaran Sekolah

Ibu Bapa dan Masyarakat : S : Sokongan

TH : Tingkah Laku

\begin{tabular}{|l|c|}
\hline Implikasi & Bilangan \\
\hline Guru dan pelajar & 13 \\
\hline Pelajar & 6 \\
\hline Pelajar dan sekolah & 5 \\
\hline Pelajar dan ibu bapa & 2 \\
\hline Guru, pelajar dan ibu bapa & 3 \\
\hline Pelajar, sekolah dan ibu bapa & 1 \\
\hline Guru, pelajar dan sekolah & 1 \\
\hline Jumlah & 31 \\
\hline
\end{tabular}

\section{Perbincangan Kajian}

Berdasarkan hasil dapatan mendapati faktor penyelesaian masalah merupakan penyumbang tertinggi yang memberi kesan kepada daya tahan pelajar dalam pembelajaran matematik. Penyelesaian masalah merupakan proses mengaplikasikan pengetahuan yang telah diperolehi kepada satu situasi yang baru. Proses ini amat penting semasa melaksanakan aktiviti pembelajaran (Attami et al., 2020). Jika proses tersebut terganggu disebabkan kesukaran pelajaran tersebut maka memberi kesan psikologi terhadap pelajar berkenaan.

Antara sebab pelajar mengalami kesukaran adalah bahasa atau komunikasi dalam matematik, mengingati semula pengetahuan yang sedia ada, kesukaran memahami konsep matematik, berkomunikasi secara metakognitif, salah faham dalam suatu konsep atau topik, gagal untuk memberikan justifikasi bagi setiap persoalan masalah yang diberi serta kurang pengalaman dalam penggunaan algoritma. Sedangkan penyelesaian masalah merupakan aspek utama yang ditekankan dalam matematik serta dalam proses pembelajaran dan pengajaran sejak sekian lama (Bailey, 2017; Rokhmah et al., 2019). Hujah ini turut disokong bahawa matematik dan masalah merupakan dua perkara yang tidak boleh dipisahkan dan saling berkaitan dalam kehidupan seharian. Setiap masalah memerlukan jalan penyelesaian bagi mencapai 
matlamat yang dikehendaki. Kemampuan individu tersebut untuk terus berdaya tahan mampu mengatasi masalah tersebut (Harsela \& Asih, 2020; Laelasari et al., 2019b).

Penyelesaian masalah yang dihadapi pelajar apabila tidak dapat menyelesaikan masalah abstrak dalam topik matematik yang dipelajari. Menjadi halangan dalam mempelajari matematik apabila pelajar tidak berkeupayaan menyelesaikan masalah konkrit dalam matematik (Laelasari et al., 2019b). Kesukaran penukaran masalah konkrit ke abstrak melibatkan keupayaan kognitif pelajar. Terutamanya peringkat pelajar yang belum mencapai peringkat operasi formal dalam aras perkembangan kognitif.

Bentuk geometri tiga dimensi merupakan topik yang menjadi kesukaran pelajar apabila sukar untuk menentukan luas dan isipadu suatu pepejal geometri tersebut. Kesukaran yang dihadapi pelajar menyebabkan daya tahan terhadap topik itu menjadi lemah. Akibat tersebut terdapat pelbagai faktor kemerosotan pencapaian matematik. Pelajar masih keliru menggunakan formula yang betul dalam menyelesaikan masalah yang melibatkan penentuan luas permukaan dan isipadu pepejal (Salleh \& Salleh, 2020).

Penyelesaian masalah bukan hanya dihadapi oleh pelajar namun guru juga turut merasainya. Kesukaran ini menyebabkan mereka tidak berdaya tahan dalam melaksanakan pengajaran. Perkara ini terjadi kepada bakal calon guru, guru pratikal atau guru baru. Memasuki dunia pendidikan pasti akan merasai pelbagai karenah daripada pelajar. Contohnya kesukaran memahami topik kebarangkalian dalam kalangan calon guru. Topik ini seharusnya dikuasai sepenuhnya kerana ianya adalah topik yang akan dipelajari oleh pelajar sekolah menengah (Ariyanto et al., 2017). Disebabkan perkara tersebut wujudnya gangguan emotional intelligence (EI) dalam kalangan guru kerana merasakan tidak berkemampuan menghadapi kesukaran semasa menyampaikan pelajaran matematik (Caceres Carvajal et al., 2019). Perkara ini memberi pelbagai kesan terhadap pelajar semasa aktiviti dalam bilik darjah.

Secara keseluruhan faktor menyelesaikan masalah matematik boleh dikaitkan dengan penyelesaian masalah rutin dalam kalangan pelajar. Pelajar telah terbiasa dengan penghafalan rumus, bentuk soalan dan latihan yang diberi adalah sama dan lemah penguasaan konsep sehingga terbiasa menyelesaikan soalan berbentuk rutin. Berbanding menyelesaikan soalan bukan rutin matematik yang memerlukan pelajar berfikir secara kritis dan kreatif (Salehudin \& Zakaria, 2017). Maka disebabkan kesukaran dalam penyelesaian matematik menyebabkan daya tahan dalam kalangan pelajar menjadi rendah terhadap matematik.

Terdapat topik dalam matematik yang sukar difahami pelajar apabila guru hanya menyampaikan pendekatan secara konvensional. Perubahan pendidikan menuntut perubahan dalam kalangan guru untuk mengubah suai pendekatan pembelajaran yang menerapkan kemahiran abad ke 21. Menurut Arbaa et al. (2017) kemahiran abad ke-21 dalam kalangan pelajar amat diperlukan bagi memenuhi keperluan pasaran kerja. Oleh sebab itu penerapan kemahiran ini harus dipupuk melalui pendekatan pengajaran yang berpusatkan pelajar. Terdapat beberapa pendekatan pengajaran dalam kajian ini seperti discovery learning metacognitive approach, blended learning, problem based learning dan pendekatan secara ICT (Information and Communication Technology) (Afriyanti et al., 2018; Hafiz et al., 2017; A. J. B. Hutauruk et al., 2019; Laelasari et al., 2019a; Mota et al., 2016). Pemilihan pendekatan pengajaran yang bersesuaian dapat membantu meningkatkan daya tahan pelajar terhadap pembelajaran matematik. Contohnya pendekatan secara blended learning dapat membantu guru dan pelajar dalam meningkatkan pencapaian akademik dengan bantuan alat teknologi. Pendekatan ini amat dituntut seiring dengan perkembangan teknologi agar guru dapat meningkatkan kemahiran pedagogi dalam menyampaikan bahan pengajaran, meningkatkan kemahiran dalam penggunaan alat teknologi serta menguasai sepenuhnya dengan bahan pengajaran yang digunakan semasa proses pengajaran (Laelasari et al., 2019a).

Kajian ini juga sejajar dengan Mota et al. (2016) yang menggunakan pendekatan ICT dalam membangunkan daya tahan pelajar terhadap matematik. Kelebihan penggunaan ICT dapat mengubah tingkah laku terhadap daya tahan bagi seseorang individu, meningkatkan ketahanan menghadapi kesukaran semasa mempelajari matematik. Selain itu, terdapat perbandingan antara dua pendekatan pengajaran iaitu pembelajaran secara masalah dengan discovery learning yang menunjukkan dapat 
membangunkan ketahanan pelajar terhadap matematik. Namun begitu penyelidik mencadangkan pendekatan secara masalah lebih sesuai digunakan berdasarkan hasil kajian penyelidik (Hafiz et al., 2017). Kesimpulannya pemilihan pendekatan pengajaran mampu mengubah banyak perkara seperti peningkatan daya tahan kerana pelajar merasakan satu pembelajaran yang bermakna. Pengalaman yang bermakna semasa pembelajaran dapat memberikan kesan yang positif dalam diri pelajar.

Faktor afektif merujuk kepada personaliti dan tingkah laku pelajar dan guru. Contohnya komunikasi antara guru dan pelajar yang lemah menyebabkan keyakinan pelajar terhadap matematik menjadi lemah sehingga membuatkan daya tahan dalam mempelajari matematik turut terkesan (Asih, 2021). Sikap pelajar yang merasakan tahap pencapaian matematik kurang memuaskan, tidak gembira dengan pencapaian yang diperolehi, kemahiran sosial yang lemah dan merasakan tiada sokongan daripada guru dan pihak sekolah terhadap dirinya menyebabkan kesukaran berdaya tahan dalam semasa mempelajari matematik (Findik, 2016). Pernyataan ini juga turut disetujui oleh Joy (2019) yang menyatakan motivasi dan emotional intelligence meninggalkan kesan terhadap daya tahan pelajar terhadap matematik. Pengurusan emosi memberikan kesan kepada motivasi pelajar apabila merasakan pencapaian yang diperolehi tidak memuaskan.

Guru juga turut mengalami masalah daripada segi emosi sehingga memberikan kesan kepada daya tahan semasa mengajar matematik. Perkara ini terjadi kepada guru baru atau guru pratikal semasa sesi pengajaran. Mengajar secara langsung dengan kepelbagaian latar belakang dan tingkah laku pelajar boleh menyebabkan guru berasa kurang berkeyakinan dalam menyampaikan satu konsep. Guru tidak berdaya tahan apabila kurang kepercayaan dalam diri untuk berinteraksi dengan pelajar dan mampu mengawal situasi yang melibatkan emosi dan kognitif (Caceres Carvajal et al., 2019). Oleh itu, guru baru yang telah melaporkan diri akan dibimbing oleh guru yang lebih berpengalaman supaya dapat mengurus dan mengajar dengan lebih baik. Program pembangunan guru seperti Professional Learning Community (PLC) dapat membantu guru untuk berkolaborasi dalam membangunkan pendidikan yang terbaik untuk pelajar. PLC juga merupakan satu platform dalam membangunkan professional guru sebagai seorang penyampai maklumat serta sekaligus membantu meningkatkan pencapaian pelajar (Bishop et al., 2019; Wilson, 2016). Secara kesimpulan personaliti dan tingkah laku pelajar atau guru turut memberikan kesan kepada daya tahan bagi mengharungi suatu perkara. Apabila seseorang individu tidak berdaya tahan dalam menyelesaikan suatu tugasan, mereka akan beranggapan tugasan atau subjek tersebut memang sukar dikuasai.

Bagi faktor- faktor lain adalah berkaitan pembinaan instrumen yang meliputi tiga aspek iaitu Value, Struggle dan Growth. Value merujuk kepada tanggapan pelajar bahawa mempelajari matematik itu adalah suatu yang bernilai. Nilaian tersebut dapat memberikan motivasi dan minat terhadap matematik. Struggle merujuk kepada keupayaan seseorang individu terhadap proses berfikir untuk menyelesaikan penyelesaian matematik. Keupayaan pelajar untuk mengatasi kesukaran dengan meningkatkan usaha mempelajari matematik. Growth pula bermaksud penetapan pemikiran pelajar untuk menghadapi cabaran serta mengembangkan strategi bagi mengatasi kesukaran tersebut. pembangunan pemikiran atau kognitif dapat dibentuk melalui aktiviti pembelajaran matematik (Gü, 2018). Secara keseluruhan walaupun kajian ini memberi tumpuan kepada pembinaan dan bahan pengukuran daya tahan. Namun hasil kajian ini memberi manfaat kepada bidang penyelidikan bahawa ketahanan matematik dapat diukur untuk mengetahui tindak balas seseorang individu tersebut. hasil dapatan pengukuran ini dapat digunakan oleh pihak kaunselor dalam membantu guru untuk mengenalpasti dan meningkatkan ketahanan pelajar semasa mempelajari matematik (Kooken et al., 2016).

Implikasi daya tahan terhadap guru dan pelajar merupakan implikasi tertinggi kerana hubungan guru dan pelajar merupakan satu perkaitan yang tidak boleh dipisahkan dalam dunia pendidikan. Keyakinan guru untuk menyampaikan ilmu pengetahuan adalah melalui latihan pedagogi yang kukuh. Misalnya kajian oleh Lutovac (2019) menyatakan guru pelatih atau guru yang baru memasuki dunia penguruan perlu menguasai konsep pengetahuan mata pelajaran tersebut dengan sepenuhnya. Perkara ini bertujuan dapat meningkatkan keyakinan guru dan pelajar. Elemen yang ditekan kepada guru adalah merangkumi dua elemen iaitu pendekatan pengajaran dan pengetahuan guru. Tidak boleh disangkal lagi bahawa bentuk pengajaran guru tidak boleh berada ditampuk lama. Perubahan dalam pengajaran harus mengikut kehendak semasa pelajar yang semakin berubah dan mencabar. Menurut Bakar et al. (2011) pemilihan 
pendekatan pengajaran matematik perlu berbeza dengan pelajaran lain supaya pemahaman konsep matematik dapat dikuasai dengan mudah oleh pelajar. Oleh itu implikasi kepada guru adalah melakukan perubahan corak pengajaran samaada memilih teknologi pengajaran atau kaedah pembelajaran yang berteraskan kepada pembelajaran abad ke-21. Guru perlu melakukan perubahan seperti pemilihan blended learning agar dapat meningkatkan ketahanan pelajar. perkara ini dapat menambah baik pencapaian akademik, memberi motivasi dan kestabilan emosi semasa mempelajari matematik (Fitri et al., 2019; Joy, 2019; Laelasari et al., 2019a).

Seterusnya elemen pelajar adalah menerapkan kemahiran generik iaitu kemahiran komunikasi. Terdapat hubungan daya tahan dalam matematik dan kemahiran komunikasi dalam matematik dapat meningkatkan penguasaan pelajar terhadap matematik (Asih, 2021). Pelajar yang mempunyai daya ketahanan yang tinggi turut mempunyai kemahiran komunikasi dalam matematik yang tinggi. Perkara ini turut disokong oleh Jajuri et al. (2019) bahawa revolusi perindustrian era 4.0 menyebabkan perubahan yang pantas perlu dilaksanakan kepada sistem pendidikan dengan memperkenalkan pendidikan STEM (Sains,Teknologi, Kejuruteraan dan Matematik) ke dalam peringkat sekolah lagi. Menerusi aktiviti STEM dapat menambah kekuatan dalaman pelajar dan keyakinan dalam pembelajaran. Keyakinan ini dapat diperolehi melalui kemahiran insaniah, sokongan sosial dan kecekapan dalam merancang aktiviti (Jajuri et al., 2019).

Dapatan yang seiring oleh Sidik et al. (2020) bahawa keyakinan dapat dibentuk melalui kemahiran insaniah seperti kemahiran berfikir secara kritis dan kreatif, kemahiran menyelesaikan masalah serta kemahiran komunikasi. Kesimpulannya kesan daya tahan ini dapat memberi membuka ruang kepada guru untuk melakukan perubahan dalam corak pengajaran. Hasilnya dapat dilihat apabila pelajar menunjukkan pencapaian akademik yang lebih baik, meningkatkan keyakinan dan motivasi serta penerapan kemahiran insaniah yang kukuh dalam kalangan pelajar.

Seterusnya elemen kedua adalah kesan kepada pelajar yang meliputi perubahan kepada pencapaian, keyakinan, motivasi dan kemahiran insaniah. Kajian ini mendapati tahap ketahanan pelajar boleh diukur melalui kemahiran menyelesaikan masalah (Harsela \& Asih, 2020). Pelajar yang berdaya tahan mampu menyelesaikan tugasan yang diberi walaupun dalam keadaan yang sukar. Berlainan dengan Gü (2018) dan Id et al. (2019) yang menyatakan pelajar dapat meningkatkan pencapaian akademik melalui keyakinan dalam. Pelbagai faktor dapat menentukan keyakinan pelajar seperti perkaitan memori dengan kesan yang negatif seperti kebimbangan, tertekan boleh menyebabkan kurang ketahanan dalam diri pelajar. Disamping itu pelajar yang mempunyai ketahanan yang tinggi dapat memberikan hasil pembelajaran yang diluar jangkaan. Mereka dapat menempuhi kesukaran dan halangan semasa pembelajaran matematik. Pelajar dapat memperolehi pencapaian yang lebih baik, keyakinan dan motivasi untuk terus berdaya saing dalam akademik (A. J. Hutauruk \& Priatna, 2017).

Implikasi kepada pelajar dan sekolah dengan adalah sebanyak 5 kajian yang merangkumi kepada persekitaran sekolah dan peranan kaunselor. Pelajar yang berdaya tahan dapat berkemampuan mengatasi kesulitan, menerima cabaran dan berupaya menyelesaikan masalah secara logik dan fleksibel mengikut keadaan yang dihadapi (Lee et al., 2013). Peranan sekolah untuk mewujudkan suasana persekitaran yang dapat mendorong ketahanan dalaman pelajar. Perubahan persekitaran yang dikehendaki meliputi kepada memupuk kejayaan dalam diri pelajar dan mengekalkan suasana persekitaran sekolah yang positif. Peranan pengetua selaku pihak pengurusan perlu memastikan setiap pelajar berasa yakin untuk hadir ke sekolah, sentiasa berusaha dalam pembelajaran dan mendapat bantuan untuk mengekalkan ketahanan diri (Findik, 2016).

Kepentingan kaunselor merupakan individu yang dapat menolong pelajar untuk bangkit semula bagi mengatasi keadaan yang sukar semasa di sekolah. Cadangan kajian oleh Joy (2019) menyatakan pihak kaunselor dapat membantu menetapkan semula matlamat dan minda pelajar terhadap pembelajaran matematik. Kebimbangan yang dihadapi pelajar dapat dileraikan dengan memberi peluang kepada pelajar untuk menyertai bengkel-bengkel keberkesanan dan motivasi. Perkara ini dapat menerapkan motivasi, pencapaian dan ketahanan pelajar dalam matematik. 
Sokongan daripada ibu bapa dan keluarga merupakan nadi kekuatan bagi seorang pelajar yang berdaya tahan. Terdapat 2 kajian bagi elemen ini menyatakan pelajar yang mendapat sokongan daripada keluarga mempunyai minat yang tinggi terhadap matematik. Minat ini dapat membentuk ketahanan diri apabila mereka dapat berinteraksi dan berbincang bersama keluarga mengenai masalah yang dihadapi dalam matematik (Lyakhova \& Neate, 2019). Latar belakang keluarga boleh memberi kesan kepada ketahanan pelajar seperti kajian Srikantaiah et al. (2018) menyatakan pelajar yang tinggal bersama keluarga yang tidak memberi sokongan akan memberikan kesan kepada pelajar untuk mengatasi kesukaran dalam pelajaran.

Seterusnya peranan guru, pelajar dan ibu bapa merupakan tiga pihak yang harus berkerjasama bagi memastikan pelajar sentiasa mampu bangkit semula apabila berdepan dengan keadaan yang sukar. Terdapat 3 kajian yang menyatakan seperti peranan guru dalam menyediakan kemudahan pengajaran berasaskan teknologi dapat mengekalkan ketahanan pelajar semasa dalam kelas (Mota et al., 2016). Guru perlu menyediakan bahan pengajaran yang bersesuaian mengikut tahap pengetahuan pelajar. Bahan tersebut perlu dilaksanakan oleh pelajar dengan pemantauan daripada ibu bapa. Perkara ini dapat membantu pelajar daripada segi pencapaian akademik dengan peranan guru dan sokongan ibu bapa (Rokhmah et al., 2019).

Kajian seterusnya adalah elemen yang memberi kesan kepada pelajar, sekolah dan ibu bapa serta guru, pelajar dan sekolah dengan 1 kajian. Kajian ini menerangkan terapi tingkah laku berdasarkan skema kognitif dapat meningkatkan daya tahan dalam matematik (Kahveci \& Bulut Serin, 2017). Program intervensi yang dilaksanakan oleh pihak sekolah serta kerjasama daripada ibu bapa dapat kepada pembangunan kognitif pelajar. Peranan guru, sekolah dan ibu bapa menjadi pendorong kepada pembangunan komprehensif pelajar dalam membina kekuatan ketahanan diri dan intelektual. Di samping itu ibu bapa dan guru perlu menyedari latihan yang disediakan harus mengikut kemampuan kognitif pelajar. Mereka yang menghadapi masalah dalam pembelajaran perlu diberi sokongan. Tingkah laku ibu bapa memberikan semangat dan dorongan boleh meningkatkan daya ingatan dan pengetahuan dalam matematik (Nelwan et al., 2018).

Kesimpulannya implikasi yang diterangkan dapat memberi manfaat kepada pelajar, guru, sekolah dan ibu bapa dalam memastikan ketahanan seseorang individu mampu mengharungi melepasi suatu keadaan yang menekan. Guru yang bertahan daya dapat mengatasi tekanan kerja yang mendatang, berkemampuan mengawal perasaan dan berkebolehan mengurus bebanan kerja dengan efektif. Sokongan sosial yang diterima daripada pihak sekolah dan rakan sekerja mampu mengekalkan ketahanan guru sebagai seorang untuk menjadi lebih produktif dan melaksanakan amanah yang diberi (Salmi Osman et al., 2015).

\section{Kesimpulan}

Daya tahan dalam matematik merupakan aspek dalaman yang penting bagi seseorang individu untuk mengatasi keadaan yang sukar. Kemampuan untuk bangkit semula apabila melalui keadaan yang mencabar menuntut individu tersebut untuk sentiasa berfikiran positif. Kuasa dalaman untuk membentuk konsep kendiri serta kemahiran insaniah dapat menangani permasalahan tersebut. Terutamanya kepada individu yang terlibat dalam bidang pendidikan seperti guru dan pelajar. Walaupun terdapat limitasi dalam kajian ini terhadap dua kumpulan responden serta menguji tahap daya tahan dalam pembelajaran matematik. Namun hasil dapatan dapat memberi peluang kepada guru dan pihak sekolah untuk mengubah corak pengajaran dalam penyelesaian masalah matematik. Manakala peranan kaunselor dapat membantu untuk membimbing pelajar yang mengalami masalah personaliti dan tingkah laku. Pihak sekolah juga dapat mengubah suasana persekitaran sekolah yang menyokong ketahanan pelajar. Cadangan lanjutan seperti ketahanan guru dan pelajar dalam menghadapi krisis global juga perlu diperhatikan. 


\section{Rujukan}

Afriyanti, I., Sri, T., \& Asih, N. (2018). Mathematical Literacy Skills Reviewed From Mathematical Resilience in The Learning of Discovery Learning Assisted by Schoology. Unnes Journal of Mathematics Education Research, 7(23), 71-78.

Arbaa, R., Jamil, H., \& Ahmad, M. Z. (2017). Model Bersepadu Penerapan Kemahiran Abad Ke-21 dalam Pengajaran dan Pembelajaran (Integrated Model of Infusing 21st Century Skills in Teaching and Learning). Jurnal Pendidikan Malaysia, 42(1), 1-11. https://doi.org/10.17576/JPEN-201742.1-1-11

Ariyanto, L., Herman, T., Sumarmo, U., \& Suryadi, D. (2017). Developing Mathematical Resilience of Prospective Math Teachers. Journal of Physics: Conference Series, 895(012062).

Ariyanto, L., Herman, T., Sumarmo, U., \& Suryadi, D. (2019). Prospective teachers ' mathematical resilience after participating in Problem-based Learning. Journal of Physics: Conference Series, 1280(042036). https://doi.org/10.1088/1742-6596/1280/4/042036

Asih, K. S. (2021). Mathematical Communication Skills Reviewed From Mathematical Resilience in Independent Learning and Discovery Learning Assisted by E - Learning. Unnes Journal of Mathematics Education Research, 10(79), 112-120.

Attami, D., Budiyono, B., \& Indriati, D. (2020). The mathematical problem-solving ability of junior high school students based on their mathematical resilience. Journal of Physics: Conference Series, 1469(012152). https://doi.org/10.1088/1742-6596/1469/1/012152

Bailey, J. (2017). Embedding problem-solving in a primary mathematics programme. Waikato Joumal of Education Te, 22(4), 19-31. https://doi.org/10.15663/wje.v22i4

Bakar, Z. A., \& Ismail, N. H. A. (2011). Persepsi Dan Sikap Pelajar Terhadap Pendekatan Konstruktivisme Serta Kesan Terhadap Pencapaian Dalam Mata Pelajaran Matematik Di Fakulti Pendidikan Universiti Teknologi Malaysia. Journal Of Science And Mathematics Educational, 3, 92-107. https://doi.org/10.1017/CBO9781107415324.004

Bishop, B. Y. B., Breitenbucher, A. M. Y., Sims, A. L., Montez, S., \& Swinehart-arbogast, C. (2019). The power of a PLC. The Learning Professional, 40(3), 1-3.

Caceres Carvajal, M. ., Santiago, M. C., \& Rincon Leal, O. . (2019). Emotional intelligence in the initial teacher training. Journal of Physics: Conference Series, 1329(012012). https://doi.org/10.1088/1742-6596/1329/1/012012

Cheong, L. K., Abdullah, Z., \& Nee, C. L. (2018). Siri Pendidikan Guru. Oxford Fajar Sdn.Bhd.

Findik, L. Y. (2016). What Makes a Difference For Resilient Students in Turkey? 1. Eurasian Journal of Educational Research, 62, 91-108.

Fitri, S., Syahputra, E., \& Syahputra, H. (2019). Blended Learning Rotation Model Of Cognitive Conflict Strategy To Improve Mathematical Resilience In High School Students. INTERNATIONAL JOURNAL OF SCIENTIFIC \& TECHNOLOGY RESEARCH VOLUME, 8 (December), 80-87.

Gü, N. (2018). The Turkish Adaptation of the Mathematical Resilience Scale : Validity and Reliability Study $\square$. Journal of Education and Training Studies, 6(4), 38-47. https://doi.org/10.11114/jets.v6i4.2992

Gusenbauer, M., \& Haddaway, N. R. (2020). Which academic search systems are suitable for systematic reviews or meta-analyses? Evaluating retrieval qualities of Google Scholar, PubMed, and 26 other resources. Research Synthesis Methods, 11(2), 181-217. https://doi.org/10.1002/jrsm. 1378

Hafiz, M., Darhim, \& Dahlan, J. A. (2017). Comparison of Mathematical Resilience among Students with Problem Based Learning and Guided Discovery Learning Model. Journal of Physics: Conference Series, 895(1).

Harsela, K., \& Asih, E. C. . (2020). The level of mathematical resilience and mathematical problemsolving abilities of 11 th grade sciences students in a senior high school. Journal of Physics: Conference Series, 1521(032053). https://doi.org/10.1088/1742-6596/1521/3/032053

Hendriana, H., Sumarmo, U., Carli, C., Ristiana, M. G., \& Putra, H. D. (2019). Enhancing students mathematical creative skill and resilience by using problem posing approach. Journal of Physics: Conference Series, 1318(012065). https://doi.org/10.1088/1742-6596/1318/1/012065

Hutauruk, A. J. B., Darmayasa, J. B., \& Priatna, N. (2019). Achievement of students mathematical resilience through problem based learning model with metacognitive approach. Journal of Physics: Conference Series, 1315(012051). https://doi.org/10.1088/1742-6596/1315/1/012051 
Hutauruk, A. J., \& Priatna, N. (2017). Mathematical Resilience of Mathematics Education Students. Journal of Physics: Conference Series, 895(012067).

Id, E. D., Giofr, D., \& Mammarella, I. C. (2019). Working memory, negative affect and personal assets : How do they relate to mathematics and reading literacy? PLOS ONE, 14(6), 1-17. https://doi.org/10.1371/journal.pone.0218921

Irmohizam Ibrahim, \& Muhammad Hussin. (2016). Tahap daya tahan dalam kalangan pelajar IPTA di Malaysia dan di luar negara. Jurnal Personalia Pelajar, 19(1), 75-85.

Jajuri, T., Hashim, S., \& Ali, M. N. (2019). THE IMPLEMENTATION OF SCIENCE , TECHNOLOGY, ENGINEERING AND MATHEMATICS ( STEM ) ACTIVITIES AND ITS EFFECT ON STUDENT' S ACADEMIC RESILIENCE. A sia Pacific Journal of Educators and Education, 34, 153-166.

Jamaludin, N. I., Shahimi, S., Bibi, L., \& Hameed, M. (2020). Elemen Kepercayaan Sebagai Teras Sumbangan Melalui Pendanaan Awam Bertujuan Kebajikan. Asian Journal of Accounting and Governance, 13, 55-65. https://doi.org/10.17576/ajag-2020-13-05

Joy, U. C. (2019). Achievement Motivation And Emotional Intelligence As Predictors Of Mathematical Resilience Among Secondary School Students. Advances in Social Sciences Research Journal, 6(5), 191-200.

Joyce, S., Shand, F., Tighe, J., Laurent, S. J., Bryant, R. A., \& Harvey, S. B. (2018). Road to resilience: A systematic review and meta-analysis of resilience training programmes and interventions. $B M J$ Open, 8(6), 1-9. https://doi.org/10.1136/bmjopen-2017-017858

Kahveci, G., \& Bulut Serin, N. (2017). Conjoint Behavioral Consultation, Cognitive Behavior Therapy and Schema-based Instruction: Enhancing Mathematical Resilience. EURASIA Journal of Mathematics Science and Technology Education, 8223(8), 5543-5556. https://doi.org/10.12973/eurasia.2017.00850a

Kharlamov, A. (2016). Systematic Literature Review Step-By-Step. 62. https://doi.org/10.5281/ZENODO.165773

Kooken, J., Welsh, M. E., Mccoach, D. B., Johnston-wilder, S., \& Lee, C. (2016). Development and Validation of the Mathematical Resilience Scale. Measurement and Evaluation in Counseling and Development, 49(3), 217-242. https://doi.org/10.1177/0748175615596782

Laelasari, Darhim, \& Prabawanto. (2019a). Analysis of students ' mathematical resilience ability on linear program material through blended learning. Journal of Physics: Conference Series, 1321(032065), 1-9. https://doi.org/10.1088/1742-6596/1321/3/032065

Laelasari, Darhim, \& Prabawanto, S. (2019b). Analysis of students ' mathematics resilience abilities on linear program material. Journal of Physics: Conference Series, 1280(042005). https://doi.org/10.1088/1742-6596/1280/4/042005

Lee, C., Garton, E., Goodlad, S., \& Brindley, J. (2013). Developing coaches for mathematical resilience Conference Item.

Lichtman, M. (2014). Qualitative Research For The Social Sciences. SAGE.

Liskin, J. E. (2011). Review Policy. The Modern Language Journal, 95, 665-668.

Lutovac, S. (2019). Pre-service mathematics teachers narrated failure: Stories of resilience. International Journal of Educational Research, 98(September), 237-244. https://doi.org/10.1016/j.ijer.2019.09.006

Lyakhova, S., \& Neate, A. (2019). Further Mathematics, student choice and transition to university: part 1 -. Teaching Mathematics and Its Applications, 38(June 2018), 167-189. https://doi.org/10.1093/teamat/hry013

Mohamed Berawi, F. (2017). Metodologi Penyelidikan Panduan Menulis Tesis. Penerbit Universiti Utara Malaysia.

Mota, A. I., Oliveira, H., \& Henriques, A. (2016). Developing Mathematical Resilience : Stu dents ' Voice About the Use of ICT in Classroom. Electronic Journal of Research in Educational Psychology, 14(38), 67-88.

Mullet, D. R., Kettler, T., \& Sabatini, A. (2018). Gifted Students' Conceptions of Their High School STEM Education. Journal for the Education of the Gifted, 41(1), 60-92. https://doi.org/10.1177/0162353217745156

Nelwan, M., Vissers, C., \& Kroesbergen, E. H. (2018). Coaching positively in fl uences the e ff ects of working memory training on visual working memory as well as mathematical ability. Neuropsychologia,

113(December

2017),

140-149. 
https://doi.org/10.1016/j.neuropsychologia.2018.04.002

Paez, A. (2017). Gray literature: An important resource in systematic reviews. Journal of EvidenceBased Medicine, 10(3), 233-240. https://doi.org/10.1111/jebm.12266

Ramli, I. S. M., Maat, S. M., \& Khalid, F. (2019). Learning Analytics in Mathematics: A Systematic Review. International Journal of Academic Research in Progressive Education and Development, 8(4), 436-449. https://doi.org/10.6007/IJ ARPED/v8-i4/6563

Rokhmah, K. N., Retnawati, H., \& Solekhah, P. (2019). Mathematical resilience : Is that affecting the students ' mathematics achievement? Journal of Physics: Conference Series, 1320(012036). https://doi.org/10.1088/1742-6596/1320/1/012036

Saleh, N. S., \& Rosli, M. S. (2019). Kepentingan Pembelajaran Abad ke 21 terhadap Potensi Kebolehpasaran Modal Insan. Innovative Teaching and Learning Journal, 2(2), 71-81.

Salehudin, N. N., \& Zakaria, E. (2017). Sikap dan Keupayaan Pelajar dalam Menyelesaikan Masalah Matematik Bukan Rutin. Persidangan Antarabangsa Sains Sosial \& Kemanusiaan.

Salleh, F., \& Salleh, S. M. (2020). Pembangunan Aplikasi Pembelajaran 3D Maths Untuk Topik Bentuk Geometri 3 Dimensi Berasaskan Android. Innovative Teaching and Learning Journal, 3(2), 80-91.

Salmi Osman, M., Chong Abdullah, M., Aziz Ismail, A., Roslan, S., Kebangsaan Taman Melawati, S., Melawati, T., Asas Pendidikan, J., \& Pengajian Pendidikan, F. (2015). Daya Tahan dalam Kalangan Guru Alaf 21. International Journal of Education and Training (InjET), 1(12), 1-9. http://www.injet.upm.edu.my

Santiago Carrillo, M. C., Vergel Ortega, M., \& Rojaz Suarez, J. . (2019). Mathematics, resilience and development of thinking of youth. Journal of Physics: Conference Series, 1408(012012). https://doi.org/10.1088/1742-6596/1408/1/012012

Sidik, I. F., Awanag, M. M., \& Ahmad, A. R. (2020). Keterlibatan Pelajar dan Hubungannya dengan Kemahiran Insaniah. Jurnal Pendidikan Malaysia, 45(01SI), 68-74. https://doi.org/10.17576/jpen2020-45.01si-09

Srikantaiah, D., \& Eichhorn, M. M. (2018). Determination of Marginalized Youth to Overcome and Achieve in Mathematics : A Case Study From India. Global Education Review, 5, 5-28.

Wilson, A. (2016). From Professional Practice to Practical Leader: Teacher Leadership in Professional Learning Communities. International Journal of Teacher Leadership, 7(2), 45-62.

Zanty, L. S., Kusuma, Y. S., \& Soemarmo, U. (2019). Mathematical resilience analysis of senior high school students. Journal of Physics: Conference Series, 1315(012074). https://doi.org/10.1088/1742-6596/1315/1/012074 